\title{
Present problems in the culture of the larvae of Ostrea edulis
}

\author{
P. R. WALNE \\ Shellfish Culture Unit, Fisheries Experiment Station; Conway, Great Britain
}

\begin{abstract}
KURZFASSUNG: Gegenwärtige Probleme bei der Larvenaufzucht von Ostrea edulis. Obgleich die Zuchtbedingungen für die Larven der Auster Ostrea edulis größtenteils bekannt sind und in einigen Ländern kommerziell ausgewertet werden, sind auch bei Anwendung standardisierter Zuchtmethoden beträchtliche Wachstumsschwankungen der Larven festgestellt worden. Auf der Suche nach dafür verantwortlichen Faktoren ließen sich bei Zuchtexperimenten mir Austernlarven, die 1969 in Conway (Großbritannien) durchgeführt wurden, geringfügige qualitative Veränderungen in der Beschaffenheit des Meerwassers nachweisen. Im Winter und zeitigen Friihjahr, als zahlreiche Schwebstoffe auftraten, war das Larvenwachstum reduziert, obgleich das Seewasser vor Gebrauch filtriert wurde. Innerhalb dieses Zeitraums wurden starke Schwankungen des Gehalts an gelöstem Zink festgestellt, die wahrscheinlich zeitweilig toxische Werte erreichten. Eine spätere Wachstumsdepression ging mit einer Algenblüte, einer Massenvermehrung von Phaeocystis pouchetti, einher. Im Juli und August wurden bakterielle Erkrankungen festgestellt. Deren Bekämpfung sowie die Isolierung der verantwortlichen pathogenen Bakterien sind wichtige Aufgaben für eine erfolgreiche Massenzucht. Zur Zeit können Austern nur durch Lebendfutter ernährt werden. In Zukunft könnte die Verwendung von Algentrockenfutter bzw. geeigneter Futtermischungen möglicherweise auch ökonomische Bedeutung für die Austernzucht erlangen.
\end{abstract}

\section{INTRODUCTION}

The cultural requirements of larvae of the European flat oyster Ostrea edulis have been studied for a long time, and the effects of a considerable number of physical and biological factors on growth, survival and metamorphosis of larvae are well known. A great deal of the work has been in the laboratory with sufficient small-scale trials being made to test the importance of a factor, but we can now see a new dimension coming with the rapidly expanding interest in culture on a commercial scale. Work of this type supplies data on the variations in growth and yield which are obtained when a standard technique is employed over a long period, and studies on the causes of these variations will undoubtedly show the importance of factors which may at present be unsuspected. As large-scale culture depends, to varying degrees, on natural products some variation in their quality is inevitable, but the more that these can be standardized, the more reliable and even will be the cultural success.

An additional point of importance is that, at the present stage of development in larval culture, most studies have concentrated on the importance of factors considered 
in isolation. The whole field of the interaction of factors, which may only have a minor effect when tested individually, still requires examination.

\section{LARGE-SCALE CULTURE AT CONWAY}

The variations which occur in larval growth are illustrated by the results obtained at Conway in 1969. In Figure 1 the histogram shows the average daily increase in shell length of larvae grown in standard conditions in 31 consecutive weeks beginning 6 January 1969; each value is the mean of the results obtained from several cultures. The method of culture, outlined in the following paragraphs, was not changed during this period of 31 weeks and was similar to that described in detail in WALNE (1966) with modifications based on subsequent work. Considerable variations in the growth rate occurred and the causes of some of these are discussed later in this paper.

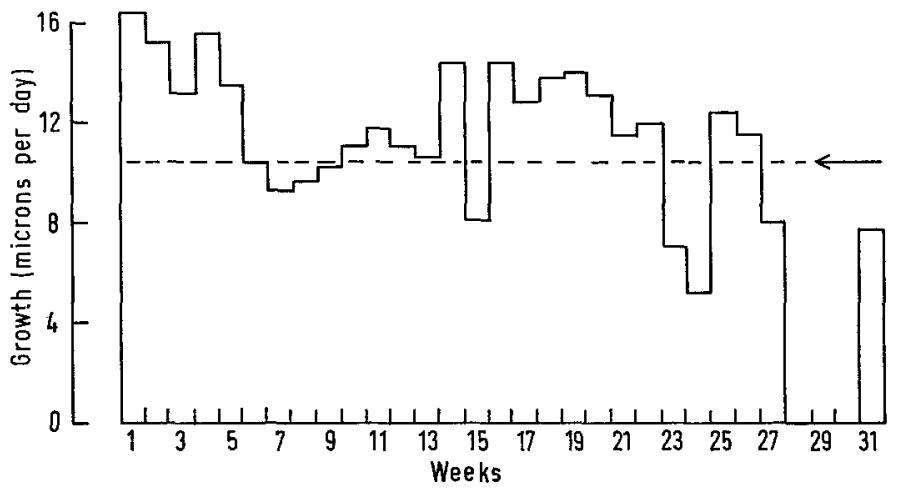

Fig. 1: Growth of Ostrea edulis larvae in standard culture conditions at Conway during 31 weeks beginning 6 January 1969

Larvae were collected from natural liberations of parent stock kept in small tanks of running sea water warmed to $20^{\circ}-22^{\circ} \mathrm{C}$. The larvae were thoroughly washed and then sufficient suspension to contain 100,000 larvae was added to 75 litres of filtered sea water in a polythene bin. The water had first been filtered through a plastic plate filter using diatomite as a filter aid, warmed to $20^{\circ}-22^{\circ} \mathrm{C}$ in a glass heat exchanger, and finally sterilized by passage through an ultra-violet unit. A mixture of penicillin and streptomycin was added for bacterial control and sufficient algal culture (obtained from 20-litre semi-continuous cultures) to give a concentration of 50 cells of Isochrysis galbana PARKe and 5 cells of Tetraselmis suecica (KYLIN) BUTcH. per $\mu l$. The water was kept stirred by five air jets reaching to the bottom and delivering a total of 200 litres of air per hour.

The water was completely changed every 48 hours, when the larvae were washed and then rinsed with dilute hypochlorite solution before replacement in a clean bin. During the change a sample of the larvae was removed for subsequent measuring. After 8-10 days some larvae usually showed the anatomical changes which presage 
metamorphosis, and collector material was added. This was in the form of a disc of black PVC sheet with a matt surface, which lay on the bottom of the bin to which it was sealed with a plastic-coated ring so that the larvae could not get underneath. The collector was made more attractive to the settling larvae by painting the surface with an aqueous extract of oyster flesh and allowing this to dry before use (BAYNE 1969).

Once spatfall had started it was found that better results were obtained by increasing the frequency of the water change to once daily. The disc was also changed at the same time, and the attached spat carefully brushed off. Their further culture, which will not be discussed in this paper, was in trays with a mesh base through which enriched sea water was continuously circulated.

The following sections discuss some of the factors which affected the rate of larval growth in 1969. Growth rate is a useful index of the quality of the culture conditions, since, in general terms, the faster the growth rate the better the larval survival and the larger the proportion of the original larvae which metamorphoses (WALNE 1966). It suffers from the defect that it is only a measure of the increase in length of the shell of the larvae and gives no information on changes in their biochemical composition. The development of analytical techniques which are able to handle the small volumes of material represented by a few hundred larvae would be an important additional tool in the study of larval culture.

\section{SEA WATER}

Natural sea water is a medium of considerable complexity which is liable to important changes, particularly in relation to substances present in trace amounts, through physical and biological agencies. As an indication of these changes we have throughout 1969 regularly estimated the abundance of suspended particles 2.5-5.0 microns in diameter, by means of a Coulter counter, in the sea water supplied to our oyster hatchery. A number of more detailed analyses have shown that the abundance of particles in this size range was closely correlated $(P<0.001)$ with that of particles 1.8-2.5 microns and 5.0-10.0 microns in diameter. In the period January to early May (weeks 1-20) the concentration of 2.5-5.0 micron particles varied between 17,200 and 258,000 per $\mathrm{ml}$. A comparison of the weekly average growth figures (Fig. 1) with the corresponding average particle content of the water shows a clear indication that growth was reduced in periods of high turbidity (Fig. 2). The water was filtered before it entered the larval cultures and the particle content after filtration was found to be generally independent of that of the incoming water. Therefore the effect shown in figure 2 is not due to an interaction between the larvae and the particles in suspension, but is more likely to be due to some material change in the quantity and quality of substances in solution.

Periods of high turbidity are generally co-incident with times of stormy weather, although the precise factors controlling the intensity and duration have still to be elucidated. In this period high turbidity was not related to the salinity of the water. Stormy conditions could liberate solutes from the bottom soil; conversely, some may be removed by adsorption. MILLAR \& SCOTT (1968) have shown how shaking filtered 
sea water from the Clyde with Fullers earth or with magnesium trisilicate can improve its suitability for larval growth. This does not seem to have happened with natural suspensions at Conway, and trials with a variety of adsorptive agents by my colleague, Mr. M. Helm, have failed to produce any improvement in larval growth. DAvis \& HiDu (1969) compared the effect of four turbidity-producing substances on Ostrea edulis larvae, and on two other species of bivalve larvae. They found that $O$. edulis was relatively resistant to all substances, except for natural silt at concentrations over $0.5 \mathrm{~g}$ per litre, but in these tests the larvae were grown in the presence of the silt, so that mechanical as well as adsorptive phenomena could have taken place.

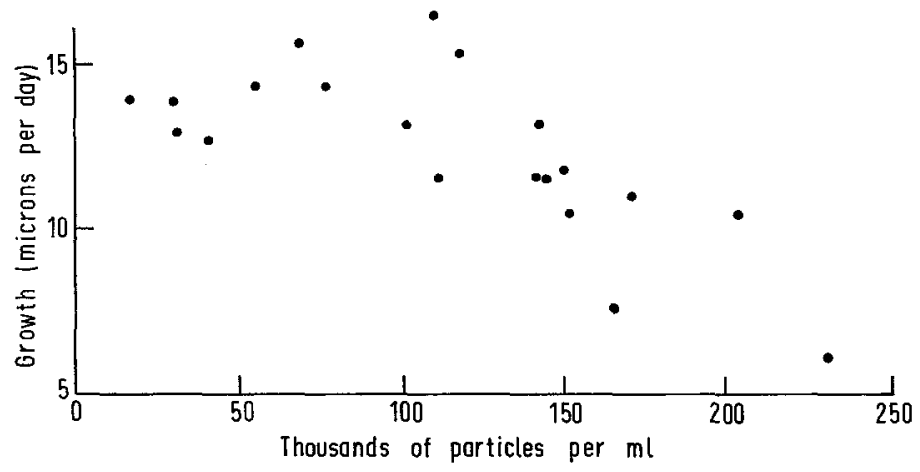

Fig. 2: Relation between growth of Ostrea edulis larvae and particle content of sea water

Some information is available on the concentration of trace metals in Conway sea water during the study period but not on any organic compounds. During 1969 Dr. H. ELDERFIELD of Imperial College, London, examined a considerable number of sea water samples from which particulate matter larger than 0.45 microns had been removed. The concentrations of a number of trace metals were determined and the most remarkable results were obtained with zinc, which varied from $0.5 \mu \mathrm{g} / 1$ to a maximum of $470 \mu \mathrm{g} / 1$. The higher values were at neap tide periods, when the salinity tended to be lower. Unfortunately the samples were not collected from quite the same source as the water used for larval rearing, and no readily observed correlation between the peaks of high zinc and the results of larval culture experiments can be seen. However, two series of trials in which Ostrea edulis larvae were reared in 1-litre beakers, to which were added various amounts of zinc, in the form of zinc sulphate, have given the following results (Tab. 1).

These experiments suggest that the higher concentrations of zinc found at times in Conway water could have markedly affected larval growth. It is planned to continue these studies both in the laboratory and by examining the trace metals in sea water from a number of other oyster grounds. Since oyster grounds typically occur in sheltered inshore areas, which are affected by land drainage, it is probable that they will receive different amounts of metals dissolved from the rocks of the drainage basin. Modern methods of chemical analysis allow these to be readily determined and it is very probable that we shall find places where, from time to time, some metals are too 
Table 1

Effect of zinc on rearing of Ostrea edulis larvae

\begin{tabular}{|ccc|}
\hline $\begin{array}{c}\text { Concentration } \\
\text { of zinc } \\
(\mu \mathrm{g} / 1)\end{array}$ & $\begin{array}{c}\text { Length increment of larvae in } \\
\text { Initial size } \\
179 \mu \mathrm{m}\end{array}$ & $\begin{array}{c}\text { Initial size }= \\
181 \mu \mathrm{m}\end{array}$ \\
\hline 0 & 45 & 41 \\
50 & - & 35 \\
100 & 26 & 39 \\
500 & 7 & 7 \\
1000 & 3 & 5 \\
2500 & - & 0 \\
5000 & 0 & 0 \\
\hline
\end{tabular}

abundant and perhaps other places where important trace elements are present in too low a concentration. It has been suggested in the past that copper is essential to the metamorphosis of the American oyster Crassostrea virginica (PRYTHERCH 1934) and although those results have not been repeated, it may be that this can only be done in certain circumstances, for example, when the parent oysters are themselves deficient in copper.

A biological source of variation which occurs regularly at Conway is the development of a bloom of the colonial alga, Phaeocystis pouchetti (HARIOT) LAGERH, which occurs in May or June. In 1969 this alga developed to a marked extent in May; by 21 May 3.1 colonies per $\mathrm{ml}$ were present in the estuary at high tide and more than 8 per $\mathrm{ml}$ were present by the end of the month. Counting the number of colonies gives only a rough index of abundance since they vary considerably in size; counting the number of cells is more precise. A number of counts of the cell concentration were made on preserved samples of Conway water by Mr. P. TYLER of the Marine Science Laboratory, Menai Bridge (Tab. 2).

Table 2

Counts of Phaeocystis pouchetti cells in Conway water

\begin{tabular}{|cc|}
\hline Date & $\begin{array}{c}\text { Number of Phaeo- } \\
\text { cystis cells per litre } \\
\left(\times 10^{-6}\right)\end{array}$ \\
\hline 12 June & 174 \\
13 June & 83 \\
16 June & 128 \\
18 June & 138 \\
20 June & 50 \\
23 June & 71 \\
25 June & 12.5 \\
\hline
\end{tabular}

At the height of the Pbaeocystis bloom there was a marked reduction in larval growth (Fig. 1, weeks 23 and 24, 9-23 June). This reduction may have been due to the biological activity of this considerable mass of biological material (the water in the main storage tanks had a thick brown colour and carried a substantial scum), or it 
may have been caused by the liberation of toxic metabolites from the disintegrating colonies. Phaeocystis has been shown in the Antarctic to have a marked antibiotic effect on micro-organisms, and this has been related to the liberation of acrylic acid (Sieburth 1968).

Some indication of the unsuitable quality of the sea water during this period is given by culture experiments made by my colleague, Mr. HeLm. In these trials larvae were reared in 1 litre beakers for four days in either natural sea water or in artificial sea water, made up according to the formula of LyMAN \& Fleming (from Svedrup et al. 1949). The average daily larval length increment obtained was as follows (Tab. 3):

Table 3

Daily larval length increment

\begin{tabular}{|c|c|c|c|}
\hline $\begin{array}{l}\text { Date of } \\
\text { experiment }\end{array}$ & $\begin{array}{c}\text { Initial length } \\
\text { of larvae } \\
(\mu \mathrm{m})\end{array}$ & $\begin{array}{c}\text { Daily length } \\
\text { Artificial } \\
\text { sea water }\end{array}$ & $\begin{array}{c}\text { Nent }(\mu \mathrm{m}) \\
\text { Natural } \\
\text { sea water }\end{array}$ \\
\hline 28 February & 227 & 12 & 10 \\
\hline 3 March & 180 & 8 & 9 \\
\hline 21 May & 180 & 15 & 14 \\
\hline 27 May & 174 & 12 & 14 \\
\hline 2 June & 173 & 10 & 8 \\
\hline 9 June & 206 & 22 & 15 \\
\hline 16 June & 211 & 15 & 3 \\
\hline 18 June & 176 & 15 & 9 \\
\hline 19 June & 188 & 12 & 2 \\
\hline 23 June & 183 & 19 & 14 \\
\hline 25 June & 208 & 15 & 12 \\
\hline
\end{tabular}

The larvae used in these experiments had been liberated from parents kept in natural sea water and they had undergone all their early development in such water, but they apparently retained a considerable growth potential which could not be expressed in the natural sea water in the period 9-23 June at the height of the Phaeocystis bloom.

In most areas the sea water will at times contain, or have recently contained, algal blooms which may affect its quality for larval rearing. For example, DAvis \& Chanley (1956) noticed that during dinoflagellate blooms at Milford their cultures failed to develop normally. Similarly, WILSON \& ARMstrong (1958 and earlier papers) reported an extensive series of experiments which showed how the development of Echinus larvae was affected by the origin of the sea water. Until the causes of these differences have been identified chemically and can be readily recognized, their impact has to be left to chance.

This consideration of dissolved substances of natural origin leads on to the problem of man-made pollution. It is now probably virtually impossible for most marine laboratories and commercial hatcheries to completely avoid this hazard, and yet there is only a small amount of information available on the levels of pollution which are important to marine larvae in the short term and none over a long period of time. Zinc, referred to earlier, apparently has an effect on growth rate at concentrations of less than $1 \mathrm{ppm}$; some detergents have an appreciable effect on growth rate at 1 to 
$2 \mathrm{ppm}$ (WALNE 1968), and $0.5 \mathrm{ppm}$ will stop the development of Crassostrea gigas eggs. The influence of pesticides on the larvae of Ostrea edulis has not yet been examined, but the experiments of Davis (1961) with the American oyster, Crassostrea virginica, suggest that they could be considerable. He found DDT to be one of the most toxic, with $0.05 \mathrm{ppm}$ causing a 90 per cent mortality of oyster larvae. O. edulis accumulates DDT and other insecticides (Connor \& PORTMAnN, unpublished), and the effect of this on their breeding potential remains to be determined.

A specialized aspect of pollution is shown by the care with which it is necessary to select the equipment for an oyster hatchery in order to avoid polluting the water. We have found it necessary to carry out a biological assay for a considerable variety of plastics. An example of these is given by the trials which we made to assist us in the selection of materials for larval culture vessels. Similarly shaped vessels holding 1 litre of water were obtained in borosilicate glass, polythene, polypropylene and fibreglass. The growth increments of larvae cultured in repeated trials showed little difference between three of the materials, but with the fourth, polypropylene, the length increment was reduced by 40 per cent. This result should not be taken to mean that polypropylene is always toxic or that the other materials are always satisfactory: it only applies to those tested batches with that particular formulation. In my opinion hard glass is the safest material to use, but this is impracticable in a number of situations.

\section{DISEASE}

A hatchery unit developed for large-scale work will culture several million bivalve larvae at a time, and will hold in various degrees of protection similar numbers of juveniles. It is inevitable that in these circumstances outbreaks of disease caused by micro-organisms will occur from time to time. The necessity for the control of bacteria is generally realized, and this has led to the widespread use of filtered water, ultraviolet lamps for water sterilization, the use of antibiotics in larval cultures and general hygienic precautions, but despite this degree of care outbreaks of bacterial disease can occur. In July 1969 we were faced with the problem of our larval cultures collapsing within a period of a few hours. The larvae would look a good colour, and be swimming actively, and yet within a few hours they could all have sunk to the bottom of the tank, and examination would show that necrosis of the larval tissues was well advanced. These symptoms spread readily throughout the hatchery and for a period (weeks 28 to 30 ) it was impossible to rear larvae. During this period a number of strains of bacteria were isolated in culture and a series of biological assays with oyster larvae showed that some had toxic properties. The effect was dramatic; a small loopful of a pathogenic culture placed in a $30-\mathrm{ml}$ suspension of larvae would result within a few hours in the death of all of them, and after 24 hours the larval tissues were almost completely decomposed. A similar amount of a non-pathogenic strain would have no effect on the larvae.

The symptoms of the disease which we encountered was similar in many respects to the description given by Tubrash et al. (1965) of lethal bacterial infections which occurred in the Milford laboratory. These authors isolated four biotypes and five antigenic types of bacteria from diseased cultures which were pathogenic to the larvae 
of five species of bivalves, including Ostrea edulis, but, rather curiously, adults were not affected. Comparative studies were made of a number of strains of similar bacteria isolated from the surrounding area, but none had antigens in common with the pathogenic group. The origin of these remains a mystery. The strains isolated at Conway have not yet been fully described; when this has been done we shall attempt to find their origin. This is clearly important for hatchery management and also leads to speculation on the importance of such outbreaks in the sea.

\section{FOOD}

There are a considerable number of reports comparing the value of different algal foods to bivalve larvae, and recent investigations (WALNE 1969) have shown that juvenile oysters have similar preferences (Tab. 4). Although future trials will probably reveal further algal species which are as good as or better than those now known, the major advances in the near future are more likely to come from an understanding of the importance of mixtures of species which have been grown under sufficiently controlled conditions to produce cells of a standard quality. Looking further into the future, it may be possible to formulate more satisfactory diets as those aspects of the biochemical and physical structure of the favourable species which are important to larval growth and metamorphosis become known.

All the reported studies on bivalve nutrition have dealt with relatively short periods of the lifespan and there are, of course, very formidable technical problems to be overcome before attempts can be made to culture several generations in a bacteria-

\section{Table 4}

The growth of Ostrea edulis spat when fed on various foods, compared with the growth of controls fed on Isochrysis. The index was calculated by dividing, for each experimental series, the largest mean size in the series on the 21 st day by the mean size of the control on that day. (After WALNE 1969)

\begin{tabular}{|llc|}
\hline Species & $\begin{array}{l}\text { Index of food value } \\
\text { Individual experiments }\end{array}$ & Average \\
\hline Monochrysis lutheri & $1.70,1.03$ & 1.36 \\
Chaetoceros calcitrans & 1.28 & 1.28 \\
Tetraselmis suecica & $1.42,1.06,1.12$ & 1.20 \\
Skeletonema costatum & $0.93,1.09$ & 1.01 \\
Isochrysis galbana & - & 1.00 \\
Dicrateria inornata & $0.85,1.04$ & 0.94 \\
Cryptomonas sp. & $0.54,0.74$ & 0.64 \\
Cricosphaera carterae & $0.41,0.83,0.61$ & 0.62 \\
Cblorella stigmatophora & $0.65,0.56$ & 0.60 \\
Phaeodactylum tricornutum & $0.62,0.43,0.73$ & 0.59 \\
Olisthodiscus sp. & $0.47,0.71$ & 0.56 \\
Nonnocbloris atomus & $0.60,0.60,0.41$ & 0.54 \\
Chlorella autotrophica & $0.37,0.66$ & 0.52 \\
Pavlova gyrans & $0.69,0.32$ & 0.50 \\
Micromonas minutus & $0.50,0.40,0.42$ & 0.44 \\
Dunaliella euchlora & 0.40 & 0.40 \\
Dunaliella tertiolecta & $0.36,0.42$ & 0.39 \\
Chlamydomonas coccoides & $0.26,0.33$ & 0.30 \\
\hline
\end{tabular}


free environment. If this is done, no doubt deficiencies in diets which are otherwise suitable for growth would become apparent, as has occurred with Heteramoeba (Droop 1966) and with Artemia and Tigriopus (Provasoli et al. 1959). This aspect of the suitability of a diet may not be important in general hatchery work, but our present studies are showing substantial short-term effects. Diets which are generally suitable for the growth of larvae or juvenile oysters may nevertheless show deficiencies at metamorphosis.

For a number of years we used one algal species, Isochrysis galbana, as food for bivalve larvae (WALNE 1966). This gave reasonably good results but it is not an easy species to culture routinely on a large scale. A search for a more suitable species showed that, on balance, equally good growth could be obtained with Tetraselmis suecica, and if a mixture of the two species was used a synergistic effect was obtained; the mixture gave an enhanced growth rate compared with either species on its own. We have found this effect with several mixtures of good food organisms, but at present it is doubtful if we have found a clear case of a synergistic effect with a mixture of a good food and a poor food.

Helm (unpublished) has examined the value of a mixture of these two species in more detail, and has also included the diatom Chaetoceros calcitrans (PAUlSEN) TAKANO, which has been used extensively by KanNo (1965), and which we find to be approximately equal in food value to Isochrysis and Tetraselmis. When larvae are cultured, from liberation, on a mixture of any two of these species, after eight days they are significantly larger $(P=<0.02)$, a greater proportion are eyed $(P=<0.05)$, and a larger number of spat are obtained $(P=<0.05)$ than from any of the foods fed singly. A mixture of all three foods did not generally produce better results than the two-food mixtures.

A further important point which emerged from these experiments was that the juveniles which have been derived from larvae fed on mixed foods grew faster, and had a lower mortality rate, than those fed on single foods, although all received the same diet after metamorphosis. Apparently, the diet of the larvae can have an appreciable effect on the vitality of the juveniles and this has important implications for commercial culture. In some areas it may be possible to achieve, for at least part of the season, a satisfactory mixture by only coarsely filtering the sea water, so that the larvae are feeding on the natural nannoplankton, perhaps reinforced by the addition

Table 5

Variation of gross composition of Isochrysis galbana. Analyses in 1961

\begin{tabular}{|cccc|}
\hline No. & $\begin{array}{c}\text { Carbohydrate } \\
\left(\mu \mathrm{g} \text { for } 10^{6} \text { cells }\right)\end{array}$ & $\begin{array}{c}\text { Protein } \\
\left(\mu \mathrm{g} \text { for } 10^{6} \text { cells }\right)\end{array}$ & $\begin{array}{c}\text { Packed cell volume } \\
(\mu 1 \text { per 10 cells })\end{array}$ \\
\hline 1 & 2.3 & 7.5 & 0.08 \\
2 & 2.5 & 7.5 & 0.16 \\
3 & 3.2 & 8.1 & 0.10 \\
4 & 3.7 & 9.4 & 0.12 \\
5 & 2.7 & 8.8 & 0.08 \\
\hline Average & 2.9 & 8.3 & 0.11 \\
\hline
\end{tabular}


of cultured algae. The disadvantage of this is its uncertainty, and a more strictly controlled diet is to be preferred.

Some results which we have show that the gross composition of the algae used for food can vary from time to time. Miss D. M. CollyeR made some analyses in 1961 of our Isocbrysis grown in 20-litre semi-continuous cultures (Tab. 5).

In 1969 a further series of analyses (Tab. 6) was carried out by Dr. C. P. SPENCER of the Marine Science Laboratory, Menai Bridge (personal communication). These two sets of analyses show how our usual practice of feeding 50 cells per $\mu \mathrm{l}$ of Isochrysis to the larval cultures can lead to considerable differences in the food concentration. On the basis of the latter data "starch as glucose" can vary between 25 and $595 \mu \mathrm{g}$ per litre, protein between 50 and $610 \mu \mathrm{g}$ per litre, and the algal volume between 2900 and $5500 \mu^{3}$ per $\mu l$. The effect of these variations on larval growth is the subject of further study.

Table 6

Variation of gross composition of Isochrysis galbana. Analyses in 1969

\begin{tabular}{|lccc|}
\hline No. & $\begin{array}{c}\text { Starch as glucose } \\
\left(\mu \mathrm{g} \text { for } 10^{6} \mathrm{cell} s\right)\end{array}$ & $\begin{array}{c}\text { Protein } \\
\left(\mu \mathrm{g} \text { for } 10^{6} \text { cells }\right)\end{array}$ & $\begin{array}{c}\text { Median cell volume } \\
\left(\mu \mathrm{m}^{3}\right)\end{array}$ \\
\hline 1 & 2.2 & 7.4 & - \\
2 & 4.0 & 6.4 & - \\
3 & 6.8 & 1.0 & 900 \\
4 & 4.3 & 12.2 & 111 \\
5 & 11.9 & 6.9 & 90 \\
6 & 0.5 & 6.3 & 59 \\
7 & 1.5 & - & 85 \\
8 & 2.1 & 6.7 & 58 \\
\hline Average & 4.2 & & \\
\hline
\end{tabular}

The emphasis in bivalve rearing has been on the use of live algae. The advantages of this food, besides presumably its close resemblance to the natural diet, are that it readily remains in suspension and, most important, those cells which are not eaten do not decay and pollute the water. However, for commercial application the disadvantage of an algal diet is that the production of a sufficient quantity of algae is technically the most difficult part of the operation, and when used to feed juveniles it is relatively costly. Although harvested cultures can be kept in an acceptable condition for a few days by storage at $2^{0}-5^{0} \mathrm{C}$, production has, by and large, to match day-today requirements, and therefore the algal culture unit has to be big enough to match the peak demand of a hatchery. Some trials have been made of the food value to bivalve larvae and juveniles of unicellular algae preserved in various ways (HIDU \& UKELES 1962, WALNE 1969) and with artificial foods (CHANLEY \& NormandiN 1967), but although some success has been reported with clam larvae, trials with oyster larvae were much less successful. Considerable difficulties were encountered from the rapid proliferation of other organisms, which may, of course, have been the food source of the larvae, and from difficulties in keeping the particles in suspension. There are at least two possible ways of overcoming these difficulties: growing the larvae in axenic culture, or the use of micro-encapsulation. Larvae can be grown at very high densities; Ostrea edulis has been successfully cultured at 20,000-40,000 per 
litre, and MrLlar \& SCOTT (1967) have demonstrated that naturally liberated larvae can be freed from bacteria by using a suitable mixture of antibiotics, and these larvae will still grow satisfactorily. The use of an axenic culture would permit the use a rich medium containing nutrients, either in solution or in particulate form, without the risk of bacterial attack. Alternatively, if a micro-capsule could be developed which contained all the essential nutrients and yet had a wall which was resistant to bacterial attack but which was dissolved by the digestive enzymes of the larvae, this could be used in normal sea water.

Because juveniles eat more than larvae the problem of the cost of the food becomes significant. It is unlikely that even in an efficient automated unit the cost of suitable algae cultured under controlled conditions will be less than $1 \mathrm{~d}$ ( 1 U.S. cent) per litre and may be several times this figure. Such cultures contain about $0.25 \mathrm{~g}$ of dry algal material per litre. Small oyster spat obtained directly from a hatchery contain about $2 \mathrm{mg}$ dry meat $(1-1.5 \mathrm{~cm}$ shell length), and these have to be grown to a dry meat weight of about $0.4 \mathrm{~g}(3-3.5 \mathrm{~cm}$ shell length) before they are large enough to be laid in the sea. The faster that this can be done the better, and supplemental feeding will reduce the time that they have to be held. If it is supposed that half the increment $(0.2 \mathrm{~g})$ is to come from cultured food and that the digestive efficiency is $10-20$ per cent, then this requires 1-2 $\mathrm{g}$ of algal material per oyster, which would come from 4-8 litres of culture at a cost of $4-8 \mathrm{~d}$ (4-8 U.S. cents); this is well above the economic value of the oyster at that stage. Algae cultured in lagoons or ponds would be considerably cheaper. Dried Chlorella cultured in enriched, stirred ponds in Japan costs about 112 U.S. cents per lb (RYTHER \& BARDACH 1968), so 1-2 g would cost $0.25-0.50$ U.S. cents. This is considerably cheaper than from rigidly controlled cultures, but at present large-scale open cultures are only suitable for very hardy algal species and these have an indifferent food value for oysters. An alternative approach would be the use of a compounded diet based on land-grown cereals. This could be prepared for less than $0.05 \mathrm{~d}$ (0.05 U.S. cents) for 1-2 g, and some trials made with Crassostrea virginica have suggested that such a diet has a considerable potential (HAven 1965), although there would be substantial technical difficulties to be overcome before it could be applied on a large scale.

\section{SUMMARY}

1. The large-scale routine culture of the larvae of Ostrea edulis for 31 consecutive weeks in 1969 showed marked fluctuations in the growth rate of the larvae.

2. In the first 20 weeks the periods of reduced growth coincided with those times when the sea water was highly turbid.

3. The concentration of dissolved zinc in the sea water varied between 0.5 and $470 \mu \mathrm{g} / 1$. Laboratory experiments showed that the higher levels would be sufficient to reduce growth.

4. A bloom of Pbaeocystis pouchetti in the river reduced larval growth at the end of May.

5. In July an outbreak of a bacterial disease caused a number of larval cultures to collapse. 
6. The use of mixed species of algae as food gives a more rapid growth of the larvae, an enhanced proportion metamorphosing, and more vigorous spat compared with feeding on one species of alga.

\section{LITERATURE CITED}

BAyne, B. L., 1969. The gregarious behaviour of the larvae of Ostrea edulis L. at settlement. J. mar. biol. Ass. U.K. 49, 327-356.

Chanley, P. \& Normandin, R. F., 1967. Use of artificial foods for larvae of the hard clam, Mercenaria mercenaria L. Proc. natn. Shellfish. Ass. 57, 31-37.

Davis, H. C., 1961. Effect of some pesticides on eggs and larvae of oysters (Crassostrea virginica) and clams (Venus mercenaria). Comml Fish. Rev. 23, 8-23.

- \& Chanlex, P. E., 1956. Effects of some dissolved substances on bivalve larvae. Proc. natn. Shellfish. Ass. 46, 59-74.

- \& Hidu, H., 1969. Effect of turbidity-producing substances in sea water on eggs and larvae of three genera of bivalve mollusks. Veliger 11, 316-323.

Droop, M. R., 1966. The role of algae in the nutrion of Heteramoeba clara... In: Some contemporary studies in marine science. Ed. by H. Barnes. Allen \& Unwin, London, 269-282.

Haven, D. S., 1965. Supplemental feeding of oysters with starch. Chesapeake Sci. 6, 43-51.

HIDU, H. \& UKeLES, R., 1962. Dried unicellular algae as food for the larvae of the hard shell clam, Mercenaria mercenaria. Proc. natn. Shellfish. Ass. 53, 85-101.

Kanno, H., 1965. Experiments concerning the tank breeding of the surf clam Spisula sacha: linensis (SCHRENK). Bull. Toboku reg. Fish. Res. Lab. 25, 131-141.

Millar, R. H. \& ScotT, J. M., 1967. Bacteria-free culture of oyster larvae. Nature, Lond. 216, $1139-1140$.

- - 1968. An effect of water quality on the growth of cultured larvae of the oyster Ostrea edulis L. J. Cons. perm. int. Explor. Mer 32, 123-130.

Provasoli, L., Shiraishi, K. \& Lance, J. R., 1959. Nutritional idiosyncrasies of Artemia and Tigriopus in monaxenic culture. Ann. N.Y. Acad. Sci. 77, 250-261.

PrYtrierch, H. F., 1934. The role of copper in the setting, metamorphosis and distribution of the American oyster, Ostrea virginica. Ecol. Monogr. 4, 47-107.

RytheR, J. H. \& Bardach, J. E., 1968. The status and potential of aquaculture. Vol. 1. Invertebrate and algae culture. Clearinghouse for Federal Scientific and Technical Information, Springfield, Va. (Design: PB 177-767).

Sieburth, J. M., 1968. The influence of algal antibiosis on the ecology of marine microorganisms. Adv. Microbiol. Sea 1, 63-94.

Sverdrup, H. U., Johnson, M. W. \& Fleming, R. H., 1949. The oceans. Prentice-Hall, New York, $1087 \mathrm{pp}$.

Tubiash, H. S., Chanley, P. E. \& Leifson, E., 1965. Bacillary necrosis, a disease of larval and juvenile bivalve mollusks. 1. Etiology and Epizootiology. J. Bact. 90, 1036-1044.

WALNE, P. R., 1966. Experiments in the large-scale culture of the larvae of Ostrea edulis L. Fisbery Invest., Lond. (Ser. 2) 25 (4), 1-53 pp.

- 1968. Toxicity experiments on oyster larvae. [Quotation]. In: 'Torrey Canyon' pollution and marine life. Ed. by J. E. Smith. Cambridge, Univ. Press, 121-122.

- 1969. Studies on the food value of nineteen genera of algae to juvenile bivalves of the genera Ostrea, Crassostrea, Mercenaria and Mytilus. Fishery Invest., Lond. (Ser. 2) 26 (5).

Wilson, D. P. \& Armstrong, F. A. J., 1958. Biological differences between sea waters: experiments in 1954 and 1955. J. mar. biol. Ass. U.K. 37, 331-348.

Author's address: Dr. P. WalNe

Fisheries Experiment Station

Castle Bank

Conway, England 